\title{
COMBINATIONS MADE IN THE CHECKLIST OF THE VASCULAR
}

\section{PLANTS OF TEXAS}

\author{
Kancheepuram N. Gandhi
}

The North Carolina Botanical Garden, Department of Biology, Coker Hall, University of North Carolina, Chapel Hill, North Carolina 27599-3280 U.S.A.

\section{ABSTRACT}

Four new combinations, proposed by Gandhi in the Checklist of the Vascular Plants of Texas (Hatch, et al. 1990), are validated here.

K¿YY WORDS: Checklist, Texas, Asteraceae, Commelinaceae

In the Checklist of the Vascular Plants of Texas (Hatch, et al. 1990), Gandhi proposed four new combinations. Unfortunately, the requirements of Art. 33.2 of the International Code of Botanical Nomenclature (Greuter 1988) were not met and the combinations remain invalid. Hence, those combinations are proposed here for validation and the relevant page numbers of the Checklist are indicated.

\section{Asteraceae}

p. 119. Haplopappus spinulosus (Pursh) DC. var. chihuahuanus (B. Turner \& Hartman) Gandhi, comb. nov. BASIONYM: Machaeranthera pinnatifida (Hook.) Shinners var. chihuahuana B. Turner \& Hartman, Wrightia 5:311. 1976.

p. 120. Heterotheca subaxillaris (Lam.) Britt. \& Rusby var. psammophila (Wagenkn.) Gandhi, comb. nov. BASIONYM: Heterotheca psammophila Wagenkn., Rhodora 62:76. 1960.

p. 120. Hymenopappus scabiosaeus L'Her. var. riograndensis (B. Turner) Gandhi, comb. nov. BASIONYM: Hymenopappus artemisiifolius DC. var. riograndensis $\mathrm{B}$. Turner, Rhodora 58:305. 1956. 


\section{Commelinaceae}

p. 38. Tradescantia leiandra Torr. var. glandulosa (Correll) Gandhi, comb. nov. BASIONYM: Setcreasea leiandra (Torr.) Pilg. var. glandulosa Correll, Madroño 19:187. 1968.

\section{ACKNOWLEDGMENT}

The author thanks Dr. John T. Kartesz for helpful comments.

\section{REFERENCES}

Greuter, W. (Chairman, Editorial Committee). 1988. International Code of Botanical Nomenclature. Regnum Veg. Vol. 118.

Hatch, S.L, K.N. Gandhi, \& L.E. Brown. 1990. Checklist of the Vascular Plants of Texas. MP-1655. The Texas Agricultural Experiment Station, The Texas A\&M University System, College Station, TX. 


\section{$2 \mathrm{BHL}$ Biodiversity Heritage Library}

Gandhi, Kanchi N. 1990. "Combinations made in the Checklist of the Vascular Plants of Texas." Phytologia 69, 276-277. https://doi.org/10.5962/bhl.part.9521

View This Item Online: https://www.biodiversitylibrary.org/item/46794

DOI: https://doi.org/10.5962/bhl.part.9521

Permalink: https://www.biodiversitylibrary.org/partpdf/9521

\section{Holding Institution}

New York Botanical Garden, LuEsther T. Mertz Library

\section{Sponsored by}

The LuEsther T Mertz Library, the New York Botanical Garden

\section{Copyright \& Reuse}

Copyright Status: In copyright. Digitized with the permission of the rights holder.

Rights Holder: Phytologia

License: http://creativecommons.org/licenses/by-nc-sa/3.0/

Rights: https://biodiversitylibrary.org/permissions

This document was created from content at the Biodiversity Heritage Library, the world's largest open access digital library for biodiversity literature and archives. Visit BHL at https://www.biodiversitylibrary.org. 